\title{
THEME "INSURMOUNTABLE PAST" IN RUSSIAN AND FOREIGN LITERATURE OF THE XX CENTURY
}

\author{
Irina K. Ivanova ${ }^{1 *}$, Svetlana V. Fedyay ${ }^{2}$, Natalia Yu. Obzhogina ${ }^{3}$, Olga K. \\ Evdokimova $^{4}$, Lyudmila N. Sarbash ${ }^{5}$, Larisa V. Lyapaeva ${ }^{6}$ \\ ${ }^{1}$ Assoc. Prof., Chuvash State University, RUSSIA, leokon2@yandex.ru \\ ${ }^{2}$ Assoc.Prof. Dr., Chuvash State University, RUSSIA, sfedyaj09@mail.ru \\ ${ }^{3}$ Senior Lect., Chuvash State University, RUSSIA, obnatur@gmail.com \\ ${ }^{4}$ Assoc. Prof., Chuvash State University, RUSSIA, evdokimova.ok@mail.ru \\ ${ }^{5}$ Prof, Chuvash State University, RUSSIA, sarbash.lu@yandex.ru \\ ${ }^{6}$ Assoc. Prof., Chuvash State University, RUSSIA, lar.lyapaeva@yandex.ru
}

\begin{abstract}
The article is devoted to the theme of "insurmountable past", which is inextricably linked with the theme of war. The authors of the article show how the tragedy of war is reflected in the personality of a person, regardless of his nationality and historical time, by the example of the creative work of writers of Russian and foreign literature. In the center of attention is the novel of V. Grossman (1905-1964)" Life and destiny "(1988) and the works of Gunther Grass (1927 - 2015) "Under local anesthesia" (1969) and "The Trajectory of the crab" (2002). Turning to the work of writers of different generations, different national mentality and different fate, the authors of the article actualize the spiritual and moral problems of literature about the war: the tragic circumstances of the war and their consequences in human life. Such a conceptual and problematic theme allows us to reveal both the commonality in its interpretation by Russian and German writers, and the originality of the position of each. Prose Grossman's war does not contain images of battle scenes, the conceptual component of the Russian writer includes a philosophical, symbolist, partly religious interpretation of the designated theme: war as evil, violence, fratricide, Apocalypse, death of the soul. Gunther Grass, using the techniques of postmodern narrative, reveals the changes in the mindset of the Germans after the Second world war: from a sense of guilt to a sense of irritation and the desire for revenge, which leads to the silencing, distortion, "simplification" of history, the substitution of the concepts of "criminal" and "victim". The article builds a convincing logical series in the context of the stated theme: if the Russian writer V. Grossman showed in his novel actually the origins and causes of the" insurmountable past " in man, the German writer G. Grass with his works warns of the danger of the revival of the spirit of fascism in modern United Germany. In the course of the analysis, the authors emphasize that in the literature of the XX century, the conflict caused by war does not disappear at the end of the war itself, and this is one of the deepest problems of life and literature of the XX century.
\end{abstract}

Keywords: Russian and foreign literature of the XX century, V. Grossman, G. Grass, war, man, "insurmountable past".

\section{INTRODUCTION}

The theme of the "insurmountable past" is becoming increasingly relevant in the light of recent attempts to interpret the history of the Second world war in favor of the political interests of individuals and States. The comparison of the works of the Soviet and German writer reveals a common approach to this topic: the history of the war, transmitted with an abundance of autobiographical references, a special attitude to the Jewish theme and awareness of the war as a tragedy that can not be forgotten. 


\section{METHODOLOGY}

Turning to the topic of war, writers repeatedly used special techniques for constructing the text, for example, the labyrinth in "The Garden of Forking Paths" by J. Borges (Obzhogina, Yazykova, 2017). The usual chronotope is replaced by the author's system of space-time relations. In Grass, history is not given as a sequential chain of events, it does not fit into the usual prose writer's artistic system of "author's time", designated as "Vergegenkunft" (Ivanova, 2017, p. 60). It moves along its own special trajectory "running as it were across the chronological axis", in its own way-the way of the crab. The history of the Second world war is recreated by the author through biographies of historical and fictional characters in the perspective of poststructuralism, which is characterized by a simulative depiction of documentary as fictional and fictional as documentary (Satovskaya, 2014, p. 224). In the novel. Grossman's last letter to his mother, written by the writer's real mother in 1941 and introduced into the artistic narrative as a point of countdown to the past, to its realization, becomes such a starting point.

Grass, going into the past and using a favorite author's reception approaching the cameras that occur in the text and as a real camera black and white film, the technique of film editing, and new cross-references, consistently leads the reader to understanding exactly this - dvenadtsatyi United Germany. Grass, singling himself out as a Customer in the text of the narrative, does not seek excuses for himself, since "the past is full of teeth, and the insatiable present now, now, now prevented". (Grass, 2013, p. 4)

The material and methods of research are based on the similarity of themes, motives and techniques used by writers of different nationalities to convey the theme of the "irresistible past".

\section{RESULTS AND DISCUSSION}

The work of Gunther Grass, published in 2002 novel or, at the insistence of the author, the Novella "the Trajectory of the crab", caused a heated public debate. Turning, as many critics believe, to his constant theme of "the insurmountable past," grass tries to answer previously asked questions in a new way. The real historical event, around which the narrative is built, for many years was covered with a veil of silence. Day demise German liner "Wilhelm Gustloff", on Board which were on approximate calculations from six thousands of five hundred until ten thousands of man, surpassing in the number of victims tragedy "Titanic" and "Louisiana", day 30 January utterly mystically connects significant dates: day arrival to power fascists (1933) day birth Wilhelm Gustloff (1895) with day birth chief narrator Paul Pokriefke (1945).

The story, about which, at the insistence of the mother and a Customer (in one of the incarnations he turns out to be an autobiographical character, actually by Gunther Grass), is written by one of its direct participants, who, due to certain circumstances, would gladly refuse this role. In grass, history is also not given as a sequential chain of events, it does not fit into the usual prose writer's artistic system of "author's time", designated as "Vergegenkunft" (Ivanova, 2017, 60). It moves along its own special trajectory "running as it were across the chronological axis", in its own way-the way of the crab. The history of the Second world war is recreated by the author through biographies of historical and fictional characters in the perspective of poststructuralism, which is characterized by a simulative depiction of documentary as fictional and fictional as documentary (Satovskaya, 2014, p. 224). But why now? With this question the narrative begins. Going into the past and using a favorite author's reception approaching the cameras that occur in the text and as a real camera black and white film, the technique of film editing, and new cross-references, Grasse consistently leads the reader to understanding exactly this - dvenadtsatyi United Germany. Grass, singling himself out as a Customer in the text of the narrative, does not seek excuses for himself, since "the past is full of teeth, and the insatiable present now, now, now prevented". (Grass, 2013, p. 4)

At first glance, the history of the ship is presented with excessive detail. Just as detailed, from different angles, describes the ship chosen as the main point of intersection of all the storylines, as a well-chosen image of the tragic past of Germany, the image of Nazi Germany. His story begins with the title - "Wilhelm Gustloff" - the name of a politician functionary killed by a Jew in 1936. This man was not a hero, was not a participant in the First world war, he was just an official who served in the place with his wife for the benefit of the national socialist party. But it is not his deeds, but his death that makes him a Martyr and a hero; his death will be used to justify the persecution of the Jews.

One of the heroines, Tula, who got on the last flight of this liner being pregnant at the eighth month, constantly regrets the babies who died in 1945, but never remembers her parents and most of all laments the loss of the photo album. The concept of "home" as a place where your parents live, loses its sacred meaning. ((Evdokimova, Lyapaeva, Fedyai, 2018) Paul, born on a sinking ship, suffers most from the lack of a father: "I did not get a Father. Only interchangeable phantoms... "(Grass, 2013, 36) in turn, the son of Paul after the divorce of his parents is brought up by his mother and grandmother and, we can say, also grows up without a father. Grass at all levels emphasizes the generation gap, which may also have provoked " 
universal unconsciousness."

It is noteworthy that the theme of the "insurmountable past" In V. Grossman's novel "Life and destiny" is revealed through the story of the family of the Jewish physicist Viktor Strum, who at the beginning of the antiSemitic campaign against cosmopolitanism finds himself in isolation, but after Stalin's call acquires the status of a privileged researcher, and, in the end, suffers a moral collapse, signing an official letter containing antiSemitic slanderous statements. The image of a scientist-physicist occupies a special place in the work of V. Grossman. The writer gave Strum "his features and put into his mouth his own reflections on social and political topics" (Bocharov, 1990, p. 75). The life story of the hero reproduces important moments of the biography of the author, the key of which is the tragic story of the mother, shot by the Germans in the occupied Berdichev. The writer's mother, Ekaterina Savelievna Vitis, died in the Jewish ghetto on September 15, 1941. But before death she managed to hand recent the Premier, destined only son. Her letter was not part of a personal correspondence, but turned into a literary work inscribed in the novel "Life and Destiny"by Vasily Grossman. In the text it is addressed to the hero of the novel Victor Strum.

The bright image of his mother accompanied the writer to the end of his life. In archive W. S. Grossman housewife two letters writer to mothers, written in 1950 and 1961 s, i.e. through 9 and 20 years after its demise. Next to the letters is a photograph of a moat filled with the bodies of executed ghetto prisoners. $\mathrm{V}$. Grossman confesses to his mother: "I feel you today as alive as you were on the day when we saw you for the last time, and the same when a small boy listened to your reading aloud. And my pain is the same as it was on the day when a neighbor who lives on School street told me that you are gone and that there is no hope of finding you among the living. And I think, it seems to me, that my love and this terrible grief will not change until the day of my end" (1950). This pain is reflected in the novel "Life and destiny".

A shocked Victor strum, reading a letter to his mother, written shortly before she was killed in the Jewish ghetto, begins to doubt the expediency of his scientific activity: "there Were moments when science seemed to him a deception, preventing him from seeing the madness and cruelty of life" (Grossman, 1991, p. 72). Moreover, feeling guilty for the horrific death of his mother (he did not take her out of the occupied city in time), the hero realizes that his entire future fate is doomed: he will never be able to get rid of the "pangs of conscience", and become a "truly happy man" (Grossman,1991, p.186).

In grass's Novella, three generations living at different times are written out: a grandmother, a son and a grandson, who, according to the author, are United by one tragedy, formally connected with the death of a ship, but this is more a tragedy of the Second world War. The story of Ursula pokriefke or simply Tulla is impressive, it is "incomprehensible": a girl from a working-class family, who joined the Nazis, passed on the denunciation of the father of her close and only friend, a pregnant seventeen-year-old girl who gave birth to a son on a sinking ship in March 1945 and survived, a resident of the GDR, an ardent Communist and Stalinist, an there was an icon of the Virgin Mary, and next to it was a portrait of Comrade Stalin in a white tunic." (Grass, 2013, p. 189) Around this heroine there are real historical events, which were so rich in the XX century. But here is paradox: than more arises exactly historical facts, the more biography Tulla reminds old Testament history, where present and episode with "beating" babies - its repetitive narrative about obmenevshikh corpses babies after demise ship, and history David and Goliath, played out its grandson and Internet opponent, which suddenly is implemented in a genuine scramble. According to the medieval worldview, the time of human life is only the history of sin. Tulla is quietly going through a change of ideologies, her historical role is insignificant, but for grass, her main role is the role of the victim, which she both lives and plays. Her main appearance on the stage was to be a speech delivered at the trial, where the fate of her grandson was decided. Grandson, which was fueled by her idea of the tragedy of the ship "Gustloff" and the tragedy of the Germans who fled from the "red threat": she began to "stuff him with stories about refugees,....which, although she was not a direct eyewitness, but rumors..." (Grass, 2013, p. 173) Grandson, who took on the role of a judge, restoring alleged historical justice, played in an Internet chat, writing his story of the death of the "peace liner", in which everything can be "simplified": "but why is he conceals the fact, that simultaneously on Board were adopted more thousands of seamen-submariners and three hundred seventy girls-troops." (Grass, 2013, p. 17) or not say about anti-aircraft guns, along on his deck. Connie plays into an ideological war his grandmother was once involved in, "he looked like he'd taken on a mission." But the mission of the grandmother had failed, her speech was not heard, but she bought the boy a gun and was an accomplice to the crime. The repetition of the history of the First and Second world war for the Germans is a repetition of mistakes. Grass tries to analyze the present in terms of experience. The novel accurately reflects the stages of changes that have occurred in relation to the assessment of the German past: from guilt and hot repentance to irritation and suggestions to reconsider their attitude to Auschwitz. And the fears of T. Adorno, expressed in 1959 that the past prefer to hide, turn into statements about the" uniqueness " of national socialism (the dispute of German historians of the late eighties). There was a substitution of concepts "criminal" and "victim". 
"The crab trajectory" is grass's warning of the impasse that Germany will face if history is forgotten or distorted in favor of certain political interests. The special chronotope of Grasse is replaced by the medieval concept of time, from which the future disappears. In the novel "Under local anesthesia" in 1969 sounded the final phrase of the main character - the teacher Shtarush: "and again, and again the pain." In the Novella 2002, the pain grows, as "there will never be an end to this, never."

\section{CONCLUSION}

In Gunther grass's short story "the Trajectory of the crab", released in 2002, the author remains true to his Central theme - "the irresistible past", but takes a new angle of the problem. The story of the German liner "Wilhelm Gustloff", sunk in 1945 by torpedoes of a Russian submarine, connects not only the fate of the main characters of three generations, but also is the image of Germany, which adopted the ideas of fascism and assessing the consequences of its historical choice. Using the technique of film editing and the technique of cross-references, the author has the opportunity to show the change in the mindset of the Germans after the Second world war: from guilt to irritation and desire for revenge, which leads to the silencing, distortion, "simplification" of history, resulting in the substitution of the concepts of "criminal" and "victim". Grass not only analyzes, but also warns of the danger of reviving the medieval spirit of fascism in modern United Germany. V. Grossman is more in depth in psychological aspects of the "insurmountable past".

\section{REFERENCE LIST}

Adorno T. (2003). Negativnaya dialektika. Nauchnyy mir. P.374

Bocharov A. G. (1990) Vasily Grossman. Life. Creativity. Fate. P. 402

Grass, G. (2013)the Trajectory of the crab. Moscow. P.286

Grossman V. S. (1999).Life and destiny. Moscow. P. 704

Evdokimova, O.K., Lyapaeva, L.V., Fedyay, S.V. (2018). Concept of "Home": Creative Interpretation in Centuries (M. Lermontov, M. Tsvetaeva, G. Aigi). Bulletin of the Chuvash State Pedagogical University named after I.Y. Yakovlev. No. 2 (98). p.p. 78-84.

Ivanova I.K.(2017) Narrativnyy diskurs v tvorchestve G.Grassa i Yu.Buydy [Narrative discourse in G. Grass and Yu. Buyda's creativity] Vestnik ChGPU. no. 3. pp. 59-65

Kostyrko S. (2003). A crab that backed away. New world. no.4. Available at: http://magazines.russ.ru/novyi mi/2003/4/ko1-pr.html (accessed 09.12.2019)

Obzhogina, N.Yu., Yazykova, A.Yu. (2017). Labyrinth Of Human And Humanity Consciousness In J. Borges`s Novelism. Collection of scientific papers of young scientists and specialists. Cheboksary. pp.. $422-427$.

Satovskaya S. N. (2014). Autobiography in the novels of G. grass: the image of the autobiographical heronarrator in the historical and socio-cultural context. Philology and art criticism. No. 5.p.p. 224 URL:https://cyberleninka.ru/article/v/avtobiografizm-v-romanah-g-grassa-obraz-avtobiograficheskogogeroya-rasskazchika-v-istoricheskom-i-sotsiokulturnom-kontekste (accessed 09.12.2019)

From different points of view. (1991)."Life and destiny" by V. Grossman: collector. P.395 